\title{
PENGEMBANGAN MODEL PENILAIAN PORTOFOLIO DALAM PEMBELAJARAN MATEMATIKA BERBASIS LESSON STUDY DI SMP
}

\author{
Sumardi \\ Program Studi Pendidikan Matematika FKIP UMS \\ email :s_mardi15@yahoo.co.id
}

\begin{abstract}
The objective of this study is to know deeply the implemantation of portofolio evaluation model in teaching learning mathematics based on lesson study. This qualitative research was done at three SMP Muhammadiyah schools at Sukoharjo residence, teachers and students as a subject of the study. Data were collected by interview, test, and documentation, then analysed by interactive model. The results are (1) the teachers of the three schools do not understand completely yet about of portofolio evaluation model in teaching learning mathematics based on lesson study, process of the development from planning (making lesson study until making portofolio); (2) at the stage doing, the teachers have done correctly as stated on Lesson Plan; (3) on the reflecting, the teachers have made the students active in learning.
\end{abstract}

Keywords: portofolio evaluation, learning mathematics, lesson study

\begin{abstract}
Abstrak. Penelitian ini bertujuan untuk 1) mengetahui pemahaman guru matematika di SMP Muhammadiyah di Sukoharjo tentang penilaian portofolio, 2) mendeskripsikan pengembangan model penilaian portofolio dalam pembelajaran matematika berbasis lesson study, dan 3) mengetahui kendala-kendala dalam implementasi model penilaian portofolio dalampembelajaran matematika berbasis lesson study di SMP Muhammadiyah di Sukoharjo. Penelitian kualitatif ini dilakukan di tiga sekolah SMP Muhammadiyah Sukoharjo. Data dikumpulkan dengan teknik interview, tes, dan dokumen yang kemudian dianalisis dengan model interaktif. Hasil penelitian menunjukkan bahwa guru-guru belum memahami secara lengkap tentang evaluasi portofolio dalam pembelajaran matematik, 2) pada tahapan pelaksanaan, guru telah melakukan dengan benar seberti yang dinyatakan dalam rencana pembelajaran, dan 3) pada tahapan refleksi, guru telah membuat siswa aktif belajar.
\end{abstract}

Kata kunci: evaluasi portofolio, belajar matematik, rencana pembelajaran

\section{Pendahuluan}

Beberapa permasalahan dalam proses pembelajaran adalah pelaksanaan evaluasi yang harus dilakukan oleh seorag guru. Salah satu faktor yang menjadi kendala pelaksanaan kuriulum 2013 adalah guru merasa terbebani dengan banyaknya perangkat dalam evaluasi tersebut. Selain itu adalah bagaimana guru menyusun model evaluasi autentik yang terdiri dari kognitif, afektif dan psikhomotorik

Evaluasi menjadi salah satu fokus yang ada dalam kurikulum, berbeda dengan model-model kurikulum sebelumnya yang hanya di titik beratkan pada evaluasi kognitif saja. Banyak guru yang merasa kesulitan baik menyusun perangkat instrumen penilainnya 
maupun proses pelaksanaannya. Bertolak dari pemikiran di atas dan dalam kondisi darurat "segera mengimplementasikan teori evaluasi yang bersifat autentik", seyogyanya guru memfokuskan pada pengelolaan pembelajaran dengan strategi sesuai kebutuhan, yaitu mengembangkan pembelajaran matematika berbasis lesson study. Pembelajaran matematika dengan pendekatan scientific, sehingga dapat merangsang wawasan anak dalam rangka merespon lingkungan. Lesson study merupakan model pembinaan profesi pendidik melalui pengkajian pembelajaran secara kolaboratif dan berkelanjutan berlandaskan prinsip-prinsip kolegialitas mutual learning untuk membangun komunitas belajar (Susilo, dkk., 2009: vi). Hal ini sesuai dengan prinsip pelaksanaan pembelajaran matematika, yakni siswa harus mendapatkan pelayanan pendidikan yang bermutu, serta memperoleh kesempatan untuk mengekspresikan dirinya secara bebas, dinamis, dan menyenangkan.

Kualitas pendidikan matematika di Indonesia masih sangat rendah, hal ini terlihat dari hasi Ujian Nasional (UN) beberapa tahun terakhir yang diperjelas oleh data hasil Ujian Nasional dari Kemdikbud. Pada tahun 2014 nilai rata-rata UN matematika dari 3.773.372 siswa yang mengikuti ujian yaitu 61,00. Pada Propinsi Jawa Tengah nilai rata-rata yang dicapai siswa mencapai 55,30. Pada tahun 2015 nilai rata-rata UN matematika yang diikuti 4.123.667 peserta ujian yaitu 56,27. Sedangkan pada Propinsi Jawa Tengah memperoleh nilai rata-rata 47,43. Hasil Ujian Nasional tahun 2014 dan 2015 menggambarkan menurunnya nilai matematika yang dicapai siswa.

Berdasarkan hasil wawancara Clara (mahasiswa matematika FKIP UMS) dengan guru matematika kelas VII di SMP Muhammadiyah 1 Kartasura, diperoleh informasi bahwa prestasi belajar matematika siswa masih terbilang rendah. Permasalahan yang muncul antara lain: 1) antusiasme belajar siswa dalam pembelajaran matematika dari 35 siswa kelas VII hanya $11,43 \%, 2$ ) keberanian siswa untuk mengemukakan pendapat sudah ada, namun kemampuan siswa dalam menjawab pertanyaan masih rendah dan 3) nilai tes matematika dari 35 siswa kelas VII yang memperoleh nilai 67 hanya $30 \%$. Nilai tersebut masih dibawah Kriteria Ketuntasan Minimal (KKM) pelajaran matematika yang ditetapkan sekolah, yaitu $100 \%$ siswa telah mencapai nilai 67 . Hal yang sama juga telah dilakukan peneliti lakukana guru sekolah MTs Muhamadiyah Waru Sukoharjo dan guru SMP Muhammaiyah 1 di Sukoharjo hasilnya tidak jauh berbeda yaitu nilai matematika masih tergolong rendah dan antosias siswa terhadap pelajaran matematika sangat kurang.

Proses pembelajaran dapat ditunjang dengan menggunakan model pembelajaran. Model pembelajaran yang saat ini banyak dikembangkan adalah model pembelajaran kooperatif. Pembelajaran kooperatif muncul dari konsep bahwa siswa akan mudah menemukan dan memahami konsep yang sulit jika merasa saling berdiskusi dengan temannya. Salah satu pendekatan dalam pembelajaran yang didalamnya terdapat diskusi antar teman yaitu model pembelajaran diskusi berbasis lesson study.

Peningkatkan hasil belajar siswa dalam model pembelajaran lesson study perlu diringi suatu penilaian (assessment). Penilaian merupakan komponen yang sangat penting dalam kegiatan pembelajaran. Penilaian merupakan salah satu kegiatan yang harus dilakukan guru dan peserta didik dari serangkaian kegiatan belajar mengajar yang mereka lakukan untuk mengukur dan menilai tingkat pencapaian kurikulum. Penilaian juga digunakan untuk mengetahui kekuatan dan kelemahan yang ada dalam proses pembelajaran, sehingga dapat dijadikan dasar untuk pengambilan keputusan, misalnya apakah proses pembelajaran sudah baik dan dapat dilanjutkan atau masih perlu perbaikan dan penyempurnaan. Oleh sebab itu di samping model pembelajaran yang cocok dan proses pembelajaran yang benar perlu ada sistem penilaian yang baik dan terencana (Surapranata, 2005: 1). 
Alternatif dalam penilaian yang bisa digunakan untuk mengetahui perkembangan pengetahuan siswa yaitu assessment portofolio atau penilaian portofolio. Portofolio memberikan bahan tindak lanjut dari suatu pekerjaan yang telah dilakukan siswa sehingga guru dan siswa memiliki kesempatan mengembangkan kemampuannya. Berdasarkan permasalan tersebut, penelitian ini bertujuan untuk: 1) mengetahui pemahaman guru matematika di SMP Muhammadiyah di Sukoharjo tentang penilaian portofolio, 2) mendeskripsikan pengembangan model penilaian portofolio dalam pembelajaran matematika berbasis lesson study, dan 3) mengetahui kendalakendala dalam implementasi model penilaian portofolio dalampembelajaran matematika berbasis lesson study di SMP Muhammadiyah di Sukoharjo

\section{Metode penelitian}

Penelitian ini menggunakan metode penelitian deskriptif kualitatif. Menurut Robert Bogdan dan Taylor (Lexy J. Moleong, 2007: 3) menjelaskan bahwa desain kualitatif adalah seperangkat prosedur penelitian yang menghasilkan data desktriptif berupa kata-kata tertulis atau lisan dari orangorang yang perilaku yang dapat diamati. Penelitian ini dilakukan terhadap siswa kelas VII SMP Muhammadiyah Kartasura , MTs Muhammaiyah Waru dan SMP Muhammaiyah 1 Sukoharjo dan 3 guru dari ketiga SMP tersebut. Metode penelitian kualitatif ini sering disebut metode penelitian naturalisme karena penelitiannya dilakukan ada kondisi yang alamiah (natural setting), disebut sebagai metode kualitatif karena data yang terkumpul dan analisisnya lebih bersifat kualitatif (Sugiyono, 2013:1).

Data penelitian diperoleh dengan metode wawancara, tes, evaluasi, dan dokumentasi. Pada metode wawancara dilakukan dengan guru matematika sekolah yang bersangkutan - Tes dilakukan diawal yaitu pre tes dan diakhir pembelajaran saat materi sudah tersampaikan. Evaluasi siswa dilakukan dengan cara penilaian terhadap hasil tes dan sikap serta perilaku harian siswa yang dilakukan dengan oleh peneliti dan observer. Dokumentasi dilakukan dengan foto kegiatan pembelajaran. Teknik pemeriksaan keabsahan data dalam penelitian ini menggunakan teknik triangulasi. Menurut Sugiyono (2010: 372) triangulasi diartikan sebagai pengecekan data dari berbagai sumber dengan berbagai cara dan berbagai waktu. Untuk mencapai derajat keabsahan data yang telah diperoleh, peneliti menggunakan triangulasi sumber dan teknik untuk memperoleh data valid dan reliable. Teknik analisis data pada penelitian ini dilakukan melalui beberapa tahapan yaitu: reduksi data, penyajian data dan penarikan kesimpulan.

\section{Hasil Penelitian dan Pembahasan}

Pembahasan dalam penelitian ini berisi tentang hasil penelitian yang telah dilakukan oleh peneliti yang bekerjasama dengan guru matematika kelas VII SMP Muhammadiyah 1 Kartasura, M.Ts Muhammaiyah Waru dan SMP Muhammaiyah 1 Sukoharjo. Selama proses penelitian, implementasi penilaian portofolio berbasis lesson study membutuhkan perangkat penilaian portofolio dan perangkat lesson study yang mencakup RPP, lampiran materi, media pembelajaran,lembar kerja siswa, soal pre tes, soal post tes, dan pedoman observasi dan Instrumen penilaian portofoli besrta rubriknya. Penelitian ini memfokuskan implementasi penilaian portofolio dalam pembelajaran matematika yang berbasis lesson study.

Penelitian ini dilaksanakan selama empat kali pertemuan. Dalam setiap pertemuan meliputi3 tahap, yaitu tahap perencanaan (plan), pelaksanaan (do), dan refleksi (see). Pada tahap perencanaan (plan) menentukan kelompok lesson study, membuat Rencana Pelaksanaan Pembelajaran (RPP), membuat lembar pedoman observasi untuk guru dan siswa, soal pre tes, soal pos tes, dan lembar kerja siswa yang menggunakan penilaian portofolio beserta rubrik penilaian. Pada tahap pelaksanaan $(d o)$, guru melakukan 
proses pembelajaran sesuai RPP, observer mengamati guru dan menilai sikap serta perilaku harian siswa. Untuk tahap refleksi (see) dilakukan dalam bentuk diskusi yang diikuti seluruh kelompok kerja lesson study, observer menyampaikan tanggapan atau saran secara bijak terhadap proses pembelajaran matematika yang telah dilaksanakan.

Setelah dilakukan penelitian dengan menggunakan penilaian portofolio yang juga diberitahukan kepada siswa, pada setiap penilaian portofolio siswa mengalami peningkatan prestasi dan berlangsung lebih baik dari waktu ke waktu. Hasil penelitian ini diperkuat penelitian dari Santoso (2014) menyimpulkan bahwa portofolio sangat bermanfaat dalam memberikan informasi mengenai kemampuan dan pemahaman siswa memberikan gambaran otentik kepada guru tentang apa yang telah dipelajari siswa kesulitan dan kendala yang dialami siswa dalam belajar dan jenis bantuan yang diharapkan siswa. Instrumen dalam penilaian portofolio yaitu tentang penilaian tes yang meliputi pre test dan post test, penilaian tugas diskusi kelompok harian, penilaian sikap dan penilaian perilaku harian siswa. Dalam penilaian pre tes dan post tes yang diberikan guru selalu mengalami peningkatan rata-rata dari setiap pertemuan. Hal ini diperkuat penelitian yang dilakukan oleh Siti Fatimah (2012) yang menyimpulkan bahwa skor pretest dan posttest dapat juga digunakan untuk mengetahui hasil belajar siswa. Penilaian perilaku harian siswa juga mengalami peningkatan dari setiap pertemuan.

Penilaian perilaku harian siswa juga mengalami peningkatan dari setiap pertemuan. Hal ini dapat dilihat dari hasil penelitian yang telah dilakukan, yaitu:

1. Siswa memiliki antusias dalam menerima pembelajaran

Kemampuan siswa dalam menerima pembelajaran yang diberikan oleh guru saat berlangsungnya proses pembelajaran kelompok merupakan salah satu aspek dalam penilaian perilaku harian siswa. Hal ini dapat mempengaruhi berjalannya proses pembelajaran di kelas. Siswa lebih antusias setelah guru melakukan pembelajaran dengan pendekatan lesnon study dan penilaian portofolio pernyataan guru SMP Muhammadiyah 1 Kartosuaro )

Hal tersebut didukung oleh penelitian Clara yang menyatakan bahwa siswa yang antusias dalam menerima pembelajaran yang diberikan oleh guru meningkat. Hal ini dapat dilihat dari penelitian pertemuan pertama $(41,67 \%)$, pertemuan kedua meningkat menjadi $(69,44 \%)$, pertemuan ketiga $(80 \%)$ dan pada pertemuan keempat ada $(94,44 \%)$. Pada penelitian ini dapat dilihat bahwa setelah adanya penelitian mengenai antusias dalam menerima pembelajaran matematika siswa dalam dapat dikatakan meningkat secara signifikan setelah diterapkannya implementasi penilaian portofolio berbasis lesson study.

2, Aktif bertanya dan menjawab pertanyaan

Kemampuan siswa untuk aktif bertanya dan menjawab pertanyaan guru juga merupakan aspek dalam penilaian perilaku harian siswa. Hal ini dapat mempengaruhi berjalannya proses pembelajaran di kelas. Dalam penelitian ini siswa yang aktif bertanya dan menjawab pertanyaan yang diberikan oleh guru meningkat. Hal ini dapat dilihat dari penelitian pertemuan pertama $(32,28 \%)$, pertemuan kedua $(55,56 \%)$, pertemuan ketiga $(61,11 \%)$ dan pada pertemuan keempat $(69,44 \%)$. Pada penelitian ini dapat dilihat bahwa setelah adanya penelitian mengenai antusias dalam bertanya dan menjawab pertanyaan dalam pembelajaran dapat dikatakan meningkat secara signifikan setelah diterapkannya implementasi penilaian portofolio berbasis lesson study.

3. Gemar membaca disaat jam istirahat

Dalam penelitian ini siswa yang gemar membaca disaat jam istirahat meningkat. Hal ini dapat dilihat dari penelitian pertemuan pertama $(14,28 \%)$, pertemuan kedua $(20 \%)$, pertemuan ketiga $(42,86 \%)$ dan pada pertemuan keempat $(47,22 \%)$. Pada penelitian ini dapat dilihat bahwa 
setelah adanya penelitian mengenai siswa yang gemar membaca disaat jam istirahat meningkat dalam dapat dikatakan meningkat secara signifikan setelah diterapkannya implementasi penilaian portofolio berbasis lesson study.

4. Berpakaian rapi ke sekolah

Dalam penelitian ini siswa yang berpakaian rapi ke sekolah meningkat. Hal ini dapat dilihat dari penelitian pertemuan pertama $(57,14 \%)$, pertemuan kedua (80\%), pertemuan ketiga $(91,43 \%)$ dan pada pertemuan keempat $(94,44 \%)$. Pada penelitian ini dapat dilihat bahwa setelah adanya penelitian mengenai siswa yang berpakaian rapi dapat dikatakan meningkat secara signifikan setelah diterapkannya implementasi penilaian portofolio berbasis lesson study.

5. Berbicara sopan santun

Dalam penelitian ini siswa yang berbicara dengan sopan santun juga meningkat. Hal ini dapat dilihat dari penelitian pertemuan pertama $(62,86 \%)$, pada pertemuan kedua $(82,86 \%)$, pertemuan ketiga $(85,71 \%)$ dan pada pertemuan keempat $(94,44 \%)$. Pada penelitian ini dapat dilihat bahwa setelah adanya penelitian mengenai siswa yang berbicara sopan santun dalam pembelajaran dapat dikatakan meningkat secara signifikan setelah diterapkannya implementasi penilaian portofolio berbasis lesson study.

\section{Simpulan}

Berdasarkan hasil penelitian dan pembahasan hasil penelitian, maka dapat ditarik kesimpulan bahwa:

1. Pada pembelajaran matematika, guru SMP Muhammadiyah di Sukoharjo sudah pernah melakukan pembelajaran matematika dengan menggunakan penilaian portofolio tetapi belum didokumentasikan karena belum memahami secara jelas mengenai penilaian portofolio.

2. Proses implementasi model penilaian portofolio dalam pembelajaran matematika berbasis lesson study melalui 3 tahap, yaitu tahap perencanaan (plan), pelaksanaan (do), dan refleksi (see). Pada tahap perencanaan (plan) menentukan kelompok lesson study, membuat Rencana Pelaksanaan Pembelajaran (RPP), membuat lembar pedoman observasi untuk guru dan siswa, soal pre tes, soal post tes, dan lembar kerja siswa yang menggunakan penilaian portofolio beserta rubrik penilaian. Pada tahap pelaksanaan $(d o)$, guru melakukan proses pembelajaran sesuai RPP, observer mengamati guru dan menilai sikap serta perilaku harian siswa. Untuk tahap refleksi (see) dilakukan dalam bentuk diskusi yang diikuti seluruh kelompok kerja lesson study, observer menyampaikan tanggapan atau saran secara bijak terhadap proses pembelajaran matematika yang telah dilaksanakan. Penilaian portofolio berbasis lesson study dapat membantu siswa dalam merubah sikap, sehingga perilaku harian siswa mengalami peningkatan yang lebih baik dari waktu ke waktu.

3. Kendala yang dihadapi dalam implementasi model penilaian portofolio dalam pembelajaran matematika berbasis lesson study di SMP Muhammadiyah Sukoharjo yaitu:

a. Siswa kurang antusias dalam mengikuti proses pembelajaran dikelas.

b. Suasana kelas kurang kondusif.

c. Waktu untuk persiapan penilaian portofolio kurang efisien.

\section{Daftar Pustaka}

Kemdikbud. 2011. TIMSS (Trends in International Mathematics and Science Study). (online: http://litbang.kemdikbud.go.id/index.php/timss, diakses tanggal 22 Oktober 2015)

Martini, dkk. 2006. "Meningkatkan Kemampuan Aspek Psikomotr Melalui Pembelajaran Berbasis Laboratorium pada siswa Kelas XI IPA I SMA Negeri I Jombang.” Dalam 
Jurnal Penelitian Kependidikan. Tahun 16 Nomor 2 Desember. Hal. 245-255.

Mulyono. 2006. Meningkatkan hasil belajar matematika melalui Penggunaan Alat Peraga Petak Persegi. Jurnal Garuda : Jakarta

Moleong, Lexy J. 2007. Metodologi Penelitian Kualitatif. Bandung: Remaja Rosdakarya

Santoso, Budi. 2014. Penilaian Portofolio Dalam Matematika. Jurnal Pendidikan Matematika, Vol.1, N Roebyanto, Gunawan dkk. 2006. "Pembelajaran Geometri yang Berorientasi pada Teori van Hiele dalam Upaya Meningkatkan Pemahaman Konsep Segiempat". Dalam Jurnal Penelitian Kependidikan. Tahun 16 Nomor 1 Junio.2, pp.37

Sugiyono. 2010. Metode Penelitian Pendidikan. Bandung: CV Alfabeta

Surapranata, Sumarna. 2005. Panduan Penulisan Tes Tertulis Implementasi Kurikulum 2004. Bandung: Remaja Rosdakarya

Sumardi, Maudya Clara Virginia,2016. Implementasi Model Penilaian Portofolio DalamPembelajaran Matematika Berbasis Lesson. Naskah Publikasi Pendidkan Matematika, FKIP UMS

Sutama. 2011. "Pengelolaan Pembelajaran Matematika Berbasis Aptitude Treatment Interaction", Pidato Pengukuhan Guru Besar, Disampaikan pada Sidang Senat Terbuka UMS, Sabtu, 8 Januari 2011.

Sutama. 2010. "Metode Penelitian Pendidikan (Kuantitatif, Kualitatif, PTK, R\&D). Surakarta: Fairuz Media. 